\title{
Strategic positioning of manufacturing operations within global supply chains
}

\section{W Chandraprakaikul, T S Baines and R Y Lim}

\section{INTRODUCTION}

The competitive landscape in which businesses operate is changing rapidly [1]. With globalization, companies can reach out to almost anywhere in the world to locate their manufacturing activities [2]. This provides both opportunities as well as threats. Whether a company is located at home or abroad, competitors will still be present, offering cheaper alternatives or more sophisticated products [3]. In recent years, the manufacturing sector has been increasingly exposed to the challenges of global competition. As a result, a key challenge for a manufacturing company is to reliably position itself in the global supply chain in order to create the best possible competitive advantage. This challenge includes deciding which activities they should focus on and carry out themselves, along with those activities that should be external. Also, where are the most appropriate locations for those internal and external activities within the global supply chain network. Currently, these decisions are often made in an unstructured way and without much appreciation for the overall impact on a company's overall performance [4]. There is therefore an urgent need for research to adopt a holistic approach to define their competitive position in global supply chains. This is referred to as strategic positioning within global supply chains.

The research programme began by exploring the strategic positioning decision formation in real practice. The results from the exploratory case studies and existing contribution from literature are then synthesized to form a pilot methodology. This is captured in the form of a paper-based workbook. Subsequently, this methodology has been evaluated and refined through a primary application in two case studies with the researcher taking a role as a participant. Finally, wider applicability of the methodology has been assessed through four more case studies covering different types of manufacturing with the researcher not intervening but instead observing. The final methodology referred to in this paper as the 'SPGC methodology' (SPGC - strategic positioning within global supply chains) has demonstrated that it provides practical support to industrial decision making.

This paper is structured to first provide a background to this topic, along with the concept of strategic positioning and an overview of previous research. The research aim and programme are then described, and the final SPGC methodology is presented. Lastly the application of the methodology is discussed.

\section{BACKGROUND OF THE RESEARCH}

This section describes the background of the research starting with the industrial problem. The concept of strategic positioning is then described and finally followed by a review of previous research work on the strategic positioning decision making process.

\subsection{Industrial problem}

The UK is the sixth largest manufacturing country in the world [5]. The manufacturing industry plays a vital role in the UK economy. It generates one-sixth of the UK overall wealth and it is the UK's most innovative sector, representing three-quarters of the country's spending on business research and development $[5,6]$. It also has important implications for other industries such as the service industry. However, the overall UK manufacturing sector has been slowly declining and the sector's share of UK GDP has fallen for many years. Nevertheless, the fall in the share of manufacturing in GDP is exaggerated by the trend towards increased outsourcing of service activities, which was previously done by divisions within manufacturing companies. In addition, the potential for the sector seen by UK government remains strong in the medium and long term.

There are however many competitive pressures facing UK manufacturers such as customers demanding lower prices, the eastward expansion of the European Union, and the entry into the global marketplace of low-cost Asian 
economies. These have presented challenges for UK manufacturing. The government's strategy $[7,8]$ suggest that in the face of increasing low-cost competition, UK manufacturers will need to move up the value-added chain and embrace knowledge-intensive, high-skilled manufacturing to compete more on quality and less on price. This indicates that the key challenge for UK manufacturers depends crucially on defining their own position among companies in the manufacturing global supply chains, which needs to be tailored to the organization's context. Increasingly, these challenges cannot be effectively met by isolated change to specific organizational units, but instead depend on the relationships and interdependencies among different elements in the supply chain, and those that are unable to do so increasingly face the danger of losing their existing markets. The competitive advantage of a company is very much bound up with the dynamics of the supply chains in which it participates, and each company has its own 'position', a selection of internal and external activities that the organization owns, and controls in the supply chain.

Currently, manufacturers in the UK as well as in other countries around the world are facing the problem of finding the most advantageous position in the global supply chain network. Such decisions by the manufacturers have been carried out in a rather disintegrated manner without appreciating the overall impact on a company and its supply chain. Therefore, a holistic and integrated approach towards the decision-making process is needed.

\subsection{The concept of strategic positioning}

The term 'strategic position' has appeared in many academic publications since the 1970s, although mainly in product, marketing, and strategic management areas [9-12]. There are, however, only a small number of papers that consider this concept within the scope of manufacturing operations. Hill [13] is among the first group of researchers who defines strategic positioning in manufacturing supply chains. He defines 'position' as: 'associated with the company's internal span of process, the degree and direction of vertical integration alternatives, and its links and relationships with suppliers, distributors, and customers'. Later, there are other researchers who defined strategic positioning in supply chains including Vallespir and Kleinhans [14], Johansen and Riis [15], Baines et al. [16], and Watson et al. [17]. Vallespir and Kleinhans [14] describe strategic positioning of a company as defining the company's boundary and modifying the scope of its activity on the supply chain in order to expand vertically or, conversely, to retire from some activities. Johansen and Riis [15] present the strategic positioning of a company by proposing a framework which comprises three inter-related levels, considering a position of a company in supply chain together with the role of production. Watson et al. [17] defines a firm's position on the basis of the activities it chooses to do and not to do.

Baines et al. [16] build on their earlier work to define 'position' as a statement of where a company sits within its supply chain network. They define 'strategic positioning' as being concerned with the process of choosing those production-centred activities that an organization should carry out internally, and those that should be external and under the ownership and control of suppliers, partners, distributors, and even customers. Their work explicitly addressed the concept and process of strategic positioning in a holistic view of a supply chain. They consider there to be four sets of interactions for a typical manufacturer within supply chain network, namely; the upstream boundary with suppliers, the downstream boundary with customers, the infrastructure boundary, and the product range boundary (see Fig.1). At each of these interfaces a company has choices, the outcomes of which will modify the strategic position.

From their definition, the concept of strategic positioning seems beyond traditional concepts on designing organizational boundaries, such as make or buy, sourcing, outsourcing, and offshoring, by considering the interactions between manufacturing operations and the wider supply chain networks associated with the organization. The comparison of the strategic positioning concept with other traditional concepts impacting on supply chain boundaries is shown in Appendix 1. To illustrate the concept of strategic positioning, consider a real example from Zara. Being a fast-fashion retailer, Zara has been successful in strategic positioning within their global supply chains. Zara positions itself strategically to provide higher value to customers to increase its competitive advantage. In 2008, Zara, which has more than 1500 clothing stores serving around 73 different countries, chooses 
to have strict control of its supply chain [18]. As a result, Zara boasts an unprecedented capacity for quick response within an industry that rarely stands still. Zara has flourished on the principle of being responsible for its product all the way from initial conception to the customer. For instance, Zara only outsource the production of clothing which is not subjected to seasonal variation, whereas its competitors choose to minimize cost and risk by owning fewer assets [19]. Zara positions itself strategically by carrying out all the decision-making operations within the headquarters which provides flexibility and allows speedier decision making [20].

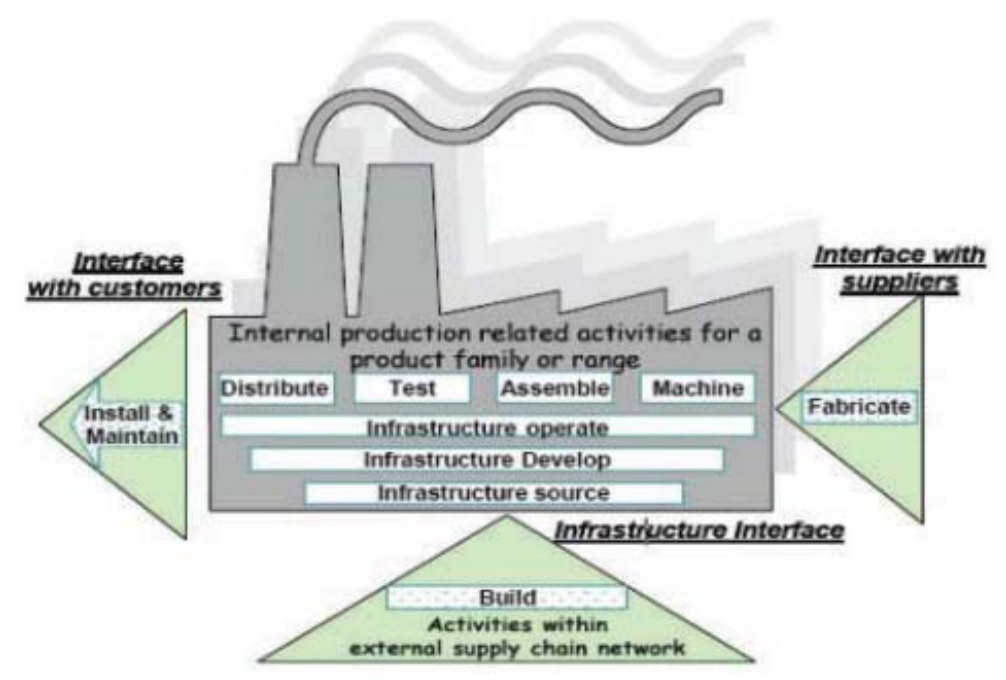

Fig.1 Four supply chain interfaces [ 16]

\subsection{Research in strategic supply chain positioning}

For research in strategic supply chain positioning, there are few research works that take a holistic view of all the four interfaces, namely with suppliers, customers, infrastructure, and product range. There are only few papers addressing on strategic positioning explicitly. Among these, Baines et al. [16] firstly instigate the concept of strategic positioning in supply chain concept by proposing a holistic view of supply chains for designing a strategic position of a company. Their work can be considered as the primary research in this area. Baines et al. [16] propose an integrated strategic positioning process that guides manufacturers through the strategic positioning decision. The decision process is aimed to encourage a holistic view of supply chain opportunities and threats, appreciate the dynamics of the organization and its environment, and link all strategic positioning decisions to competitive strategy.

In the same period, Johansen and Riis [15] proposed a framework for the strategic positioning of tomorrow's industrial company. Their framework attempts to capture future trends and challenges and transform them into a holistic industrial context to be used for strategically positioning an industrial company. Their work tends to focus strategic position of a company on archetypes and production roles but omits the process of how to make a decision for those strategic positions.

Later, Lim et al. [21] report on an investigation into the selection and evaluation of the suitable strategic positioning for small and medium-sized enterprises (SMEs) in Singapore. They selected the decision process of Baines et al. [16] as it is potentially the most suitable for SMEs in Singapore. They suggest that the methodology of Baines et al. [16] is mainly for manufacturing companies and from the perspective of multinational companies, not specifically for the SMEs. The structure of the methodology can be simplified to cater for SMEs and for different industry sectors. In 2007, Lim [22] developed a strategic positioning decision process for SMEs in Singapore by improving and tailoring the methodology of Baines et al. [16] to the requirements of SMEs in Singapore. Lim's methodology for strategic positioning has been developed to support SMEs in Singapore from the perspective of a resource-based view and for domestic positioning. In 2009, Chai et al. [23] propose the key factors that need to be considered when deciding 
production allocation in the pharmaceutical industry as well as developing a managerial framework to guide the location decision in the same industry. Their work aims to help managers to decide on the best location to maximize the overall manufacturing network.

From this review, it has been found that there are very limited research papers on strategic positioning and so far no research on methodology to support strategic global supply chain positioning. The research works by Baines et al. [16] and Lim et al. [22] deal with strategic positioning from the perspective of a single business unit dealing with its domestic supply chain interfaces and Johansen and Riis [15] focuses on archetypes of a company. Chai et al. [23] emphasize the key factors that influence production allocation decision and do not consider the linkage of the decision with the company's strategy as well as the interactions with suppliers, customers, product range, and infrastructure. Hence, the review in this section suggests that the main gap in the current literature on strategic supply chain positioning is the lack of an approach that assists manufacturing companies in strategic positioning within global supply chains.

\section{RESEARCH AIM AND PROGRAMME}

The aim of the present research was therefore to develop a generic and practical methodology that provides an integrated and holistic approach to assist practitioners to deal with SPGC. In order to achieve the research aim for this project, the following research objectives were defined.

1. Explore how strategic positioning decision formation takes place in practice and the challenges raised.

2. Evaluate and select potential methodologies related to strategic positioning within global supply chains.

3. Form a pilot methodology to aid practitioners in the strategic positioning within global supply chains decision.

4. Conduct primary evaluation of the pilot methodology to evaluate its practicability in actual use.

5. Conduct secondary evaluation of the refined pilot methodology to evaluate its wider applicability.

The research aim and objectives have naturally led to a five-phase structured research programme (Fig.2), which is outlined as follows, and led to the final decision process which is explained subsequently.

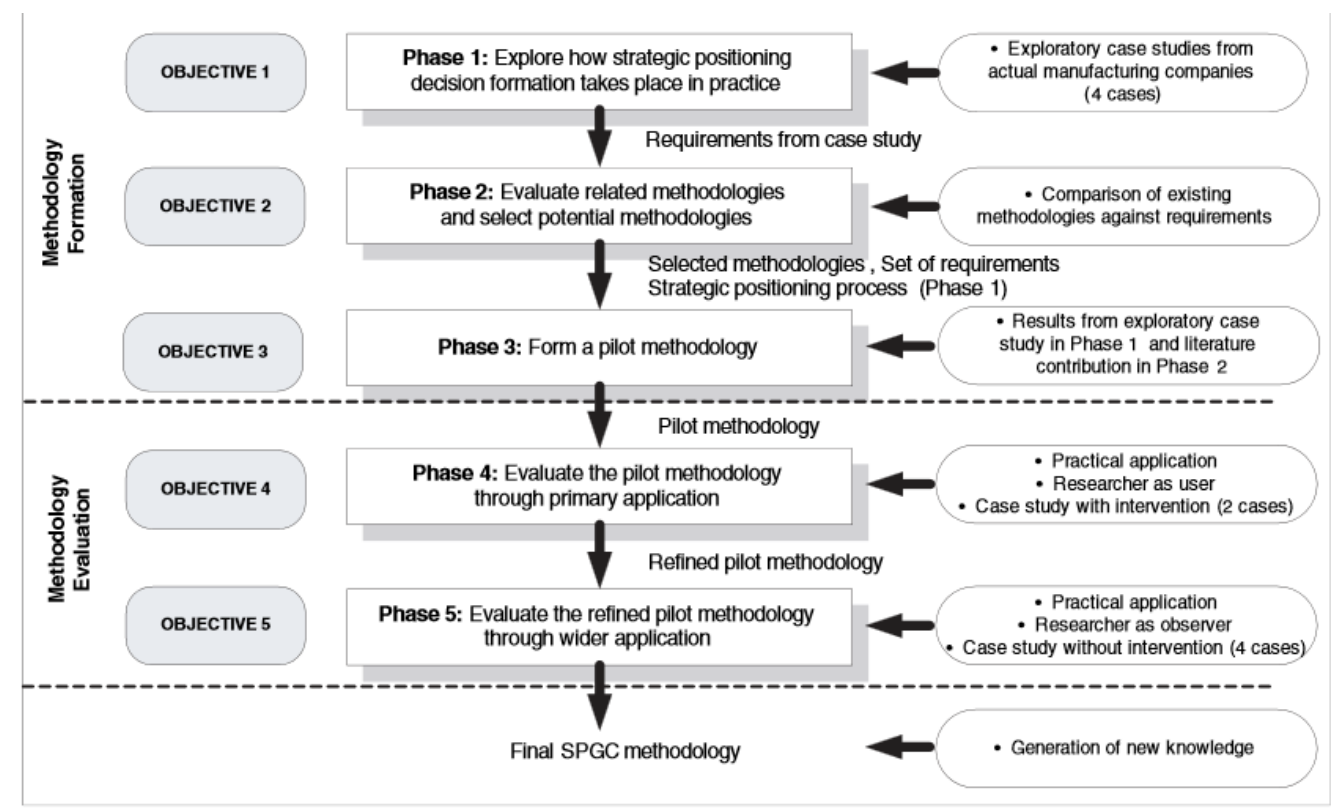

Fig.2 An overview of the research programme (adapted from Handfield and Melynk [ 24 ])

\subsection{Phase 1: explore how strategic positioning decision formation takes place in practice}

This phase of the research was to explore strategic positioning decision formation in practice. To do this, the research method preferred in this phase was the case study method because it is suitable for qualitative and 
quantitative methods, and for building theory from empirical research [25-27]. Four case studies were selected carefully in different industries to reflect the general process from leading companies. They exist in different sectors of manufacturing industry and produce different product volumes and varieties, which would reflect the similarities and contrasts of strategic positioning decisions from different perspectives, as shown in Appendices 2 and 3. Semistructured interviews were conducted with senior management in each company. The outcomes of this phase are seven key findings and a common decision process as shown in Tables 1 and 2, respectively.

Table1 Key findings from exploratory case studies

Finding 1: Practitioners at the case study companies did not all recognize the term of strategic positioning, though they considered this decision as high value and carefully made.

Finding 2: Practitioners at the case study companies all took account of the wider business strategy when forming decision affecting strategic positioning.

Finding 3: Practitioners at the case study companies all took account of core competences when forming decision affecting strategic positioning.

Finding 4: Practitioners at the case study companies all attempted to take a holistic approach when forming decisions affecting strategic positioning.

Finding 5: Practitioners at the case study companies considered a range of criteria, including cost, risk, and flexibility, when forming decisions affecting strategic positioning.

Finding 6: Practitioners at the case study companies all considered that structured methodology would be helpful when forming decisions affecting strategic positioning.

Finding 7: Practitioners at the case study companies all attempted to define clear aims, procedures, and communication within organization and other participants involved when forming decisions affecting strategic positioning.

Table2 Strategic positioning process from exploratory case studies

1. Identification phase - understand business issues, current company's position within supply chains and environment

a. Decision recognition: recognition of business issues from both inside and outside the companies

b. Business diagnosis: diagnosis of the current company's position and environment and defining the goal and objectives of the project

2. Development phase - develop actions and configurations

a. Action design: design of actions to be taken for a new position and analysis of what activities should be done internally or externally

b. Criteria design: identification of criteria for configuration selection and the suitable place for those activities

c. Configuration design: screening configuration choices into promising choices

3. Selection phase - evaluate and communicate

a. Evaluation: working on details of each promising option

b. Authorization and action plan: authorization, communication, and action plan

\subsection{Phase 2: evaluate related methodologies and select potential methodologies}

This phase was to evaluate related methodologies in strategic positioning within global supply chains and to select potential methodologies for methodology formation in phase 3. The method for conducting this phase consists of establishing requirements for the pilot methodology, evaluating the capability of existing related methodologies against the requirements, and selecting the potential methodologies. The outcomes of this phase are the set of requirements (Appendix 4), an analysis of existing methodologies, and the potential methodologies for methodology formation (Table3) in phase 3. 
Table3 The potential methodologies according to the Requirements

\begin{tabular}{|l|l|}
\hline Authors & Methodology \\
\hline Baines et al. [16] Workbook format & $\begin{array}{l}\text { Strategic positioning for manufacturers (domestic } \\
\text { context) } \\
\text { Strategic supply chain positioning methodology for SMEs } \\
\text { Lim [22] Computerized software tool }\end{array}$ \\
$\begin{array}{l}\text { in Singapore } \\
\text { Manufacturing location decisions } \\
\text { Probert[29] Workbook format } \\
\text { Developing a make or buy: strategy for manufacturing } \\
\text { business }\end{array}$ \\
$\begin{array}{l}\text { Offshore? Be sure } \\
\text { format }\end{array}$ & \\
\hline
\end{tabular}

\subsection{Phase 3: form a pilot methodology}

This phase was to form a pilot methodology based on the results in phases 1 and 2 . The method for conducting this phase was to determine the structure and the content of a new approach by mapping the decision process from the case study with the selected methodologies and analysing contents and elements needed in the pilot methodology. The combined structure and content forms the pilot methodology.

\subsection{Phase 4: evaluate the pilot methodology through primary application}

This phase was to evaluate the pilot methodology in order to determine whether the methodology provides workable and logical steps in actual use. A case study method with participant intervention was chosen to be carried out in this phase. Maylor and Blackmon [30] suggested that by using the multiple case study method the researcher can test or build a theory by looking for a pattern across the cases. Yin [31] has proposed that six to 10 case studies are considered to be adequate for multiple case studies.

A few cases (two or three) would be literal replications, whereas a few additional cases (four to six) might be designed to pursue two different patterns of theoretical replications. Thus, for the case of proving the validity of the methodology, two cases were selected for the primary testing and four cases were chosen for the secondary wider testing in the next phase. To guide the researcher in what to look for in a test-case, some criteria were developed, as shown in Appendix 5. As a result, the primary evaluation in this phase was conducted in two manufacturing companies, named Elec-co and Amp-co (see Appendix 6). The outcome of this phase was a refined pilot methodology which was ready for wider testing in the next phase.

\subsection{Phase 5: evaluate the refined pilot methodology through wider application}

This phase was to evaluate the refined pilot methodology for wider application in order to determine whether the methodology could be generic and robust and to find out whether it was useful, usable, and feasible in different environments. A case study method without intervention was selected in this phase to test the independence of the methodology from the researcher. A number of different types of cases were identified to cover the different environments of manufacturing companies including geographical location, managerial culture, industry segments, and company strategies (Appendix 7). The four selected companies named Steel-co, Garmentco, Tyre-co, Tool-co were different from those of phase 4 in order to demonstrate that the refined pilot methodology was not limited to two types of organization. Consequently, the outcome from the case studies makes the final refinement for the SPGC methodology.

\section{THE METHODOLOGY FOR SPGC}

This section describes the decision process that has been developed through the application of the research programme as described in the previous section.

\subsection{Overview of structure}

This section gives an overview of the SPGC methodology and its stages. The SPGC methodology is principally for senior executives and focuses on defining the strategic position or competitive space that a manufacturing 
organization should occupy; in other words identifying those manufacturing-related activities that should remain internal to the business, those that should be carried out by external suppliers, partners, and customers, and identifying the most appropriate locations for those internal and external activities within the global supply chain network.

The SPGC methodology has been developed to help companies to better choose their competitive space within their manufacturing global supply chains. The methodology caters for a holistic approach to consider all supply chains associated with manufacture. This means considering within the same analysis all inbound, outbound, and infrastructural supply chain issues across all products. Furthermore, the methodology links all decisions about activity ownership and configuration to competitive strategy, the market conditions, and acceptability of an initiative to the company.

As shown in Appendix 8, the final SPGC methodology comprises the following five stages that guide the actions and decisions of a project team. Each stage is completed by carrying out between three and five smaller sections of analysis. Each stage is explained in terms of what (the objective), why (the justification), how (the mechanism), and outcome (the deliverables). The specialized worksheets for each stage of the process are also provided in the methodology workbook.

An overview of the final SPGC methodology has been presented in this section. The following sections now provide a more detailed description of the analysis carried out in each of these stages.

\subsection{Stage 1: issue analysis}

The overall purpose of this stage is to produce a qualified statement that states which areas of the organization are to be analysed and some overriding issues, challenges, and performance improvements to be tackled in the project. This stage comprises five sections which may commence either proactively or reactively, as summarized in Appendix 9.

These lead the panel to consider whether all or only part of the strategic business unit should be targeted; which products and services are involved; and how these compete in the market place. Next, the review of competitiveness is undertaken by agreeing whether the company's approach to achieving competitive excellence is to be based on customer intimacy, operations excellence, or product leadership [32]. Then, through the use of a generic set of performance criteria (adopted from the work of Baines et al. [16], as explained Appendix 10), the panel is guided to identify where any gaps in performance with customer requirements and competitors exist and hence all analysis leads to the generation of the issues statement.

\subsection{Stage 2: mapping current supply chain position}

After defining the issue statement, stage 2 is to produce a current competitive space to show the position of current supply chain activities of the company. As shown in Appendix 11, there are four sections to create the current competitive space in this stage. The mapping in this stage is based on the organizational processes which have four interfaces to the supply chain, namely suppliers, customers, product range, and infrastructure. The output from this stage is the current competitive space of the company. This competitive space illustrates all activities and core activities that sit within the company, along with the external activities in the wider supply chain, which are directly related to delivering the products and services relevant to the 'issue statement' generated in the first stage.

\subsection{Stage 3: future analysis}

The objective of stage 3 is to analyse the activities that have significant impact towards the issue statement and identify immediate associated initiatives. In performing this stage, it is important to identify the significant activities which play important roles for the company to achieve the desired stage according to the issue statement. The significant activities are those that have the potential to make a significant impact on positively affecting the issue statement through a change in ownership/state. After identifying the significant activities, these activities are analysed and assessed by using decision criteria provided in the workbook in four areas (financial, 
attitude/acceptability, competence/capability, technological and strategic fit (FACTS), shown in Appendix 12). This is to propose the actions to be taken for the activities to achieve the issues on the statement and desired competitive strategies, and to minimize the competitive gaps. The output from this stage is the proposed actions which form the future competitive space of the company. To achieve this stage, there are three sections, as exhibited in Appendix 13.

\subsection{Stage 4: configuration analysis}

The objective of this stage is to identify and analyse configurations for the significant activities. After proposing the actions to be taken for the significant activities, it is necessary to consider the architecture of supply networks for the significant activities within the global supply chains which have considerable impact on the performance of the company in delivering products and services. At this stage a list of potential architectures of supply networks is identified and recorded into the provided worksheet. Then any configuration options that do not meet the company's key requirements on issue statement, competitive strategy, and competitive gaps are eliminated from the list. The process will narrow the potential configuration options further to a more manageable option by studying both benefits and risks in detail which include financial factors, geographical factors, competitive performance factors, and business risks (see Appendix 14). To achieve this stage, there are three sections, as shown in Appendix 15.

\subsection{Stage 5: selection and action plan}

The objective of this stage is to select the most appropriate configuration option and develop an action plan for implementation. During the final stage, it is important to remember that new decisions and issues from previous stages may have arisen which may not have been noted so that the project team members should discuss any area that is unclear. Finally, scores should be allocated to each option based on financial benefits, geographical benefits, performance benefits, and business risks in the provided worksheet. After completing the scoring, the project team members should be able to select the most appropriate configuration, develop a draft plan which aims to minimize risks from the selected option and finally develop an action plan. To achieve this stage, there are three parts to carry out, as given in Appendix 16.

\section{THE APPLICATION OF SPGC METHODOLOGY}

This section presents an overview of the application of the SPGC methodology in two case studies. These two case studies, Steel-co and Garment-co, were selected from four case studies in the wider application phase (phase 5) to present as examples of the application of the methodology.

\subsection{Steel-co}

The application of the methodology began with stage 1 where an issue statement was defined. The business strategies were reviewed and overriding issues were raised. The company issues included development of tool steel sales, maintenance of production equipment, efficiency of plant layout, and improvement of operator experiences. The internal and external environments were analysed to explore the strengths, weaknesses, opportunities, and threats of the company. The current competitive strategy was assessed to be Customer Intimacy and so was their desired competitive strategy as their utmost priority is customer satisfaction. The company aimed to focus on delivering what specific customers want, and cultivating relationships with customers. The summary of competitive gaps was analysed and showed that the company exceeded in Customer Intimacy. The issue statement was identified as an evaluation of manufacturing and distribution in the UK: either investing in existing plant or relocating to alternative premises (Appendix 17). In stage 2, mapping the current supply chain position identified the supply chain position (Appendix 18), activity position, and core activity position (Appendix 19). Core competences such as research and development, technical support, and complete manufacture were analysed.

In stage 3, the significant activities were identified as machining, purchasing, warehousing, sawing, heat treatment, machining for finished product, and sales and marketing. The advantages and disadvantages of keeping significant activities in-house or doing them externally were assessed by using FACTS (see Appendix 12). The decision was made 
to keep the internal and external activities the same as before. They proposed six strategic initiatives to improve the significant activities according to the issue statement. For stage 4 , the company listed three potential options and used screening factors derived from the issue statement and the desired competitive strategy to cut the list into two options. The two options were studied in depth for investment analysis, geographical analysis, performance analysis, and business risks in stage 5 . For the final stage, the decision was made to confirm the current configuration; however, the action plan was set out to improve the existing configuration with regard to the issue statement.

\subsection{Garment-co}

The application of the methodology began with stage 1 in which the project members identified the whole company as the business area for review. The business strategies focus on quality of the products and customer satisfaction as the company manufactures according to customer orders. The issues from internal and external environments were raised by the panel. The current competitive strategy was assessed to be Customer Intimacy as the company currently offers high customization to the customers. In the future the company would like to focus on best quality product and providing the best total cost and delivery on time. Clearly the desired competitive strategy of the company was assessed to be Operation Excellence, supported closely by Customer Intimacy. According to the competitive gaps analysis, Garment-co was found to have critical gaps in operational excellence relating to product availability and product price, and in product leadership it was related to time-to-market and new product introduction rate. The issue statement for Garment-co was to reduce costs, improve quality, and increase delivery on time. In stage 2, using the supply chain map, the supply chain position was analysed according to the four key supply chain interfaces (customer, supplier, infrastructure, and product range). After that, the project members identified company level activities for the activity position map (Appendix 20) and assessed the core competence of the company. The core competences were identified as sales and marketing and company image. However they realized that these core competences do not last long term as their competitors can also reach the same stage of core competency.

In stage 3, the significant activities were identified and internal/external assessment was analysed. Garment-co decided to retain the level of ownership of the significant activities. Garment-co also proposed seven strategic initiatives (Appendix 21) to be carried out for the significant activities to achieve the issue statement. For stage 4, the panel members listed potential configuration options. The potential options include retaining and improving the existing plant in Thailand, relocating manufacturing operations to Vietnam, downsizing the plant in Thailand and offshoring some manufacturing operations to Vietnam in order to take advantage of lower cost. These options were assessed in detail in stage 5 . The decision was made to improve the efficiency of the existing plant in Thailand for 2 years and review every 6 months the performance, geographical factors, financial factors, and business risks for the opportunity to set up the manufacturing operations in Vietnam.

\section{CONCLUSIONS AND FUTURE RESEARCH}

In conclusion, as more manufacturers are exposed to the global competition and encouraged to move up the value chain, the challenge is to identify the appropriate strategic position for their organizations within the global supply chains. In this paper the research was conducted to develop a decision aid that is intended to help practitioners to better choose their competitive space within their manufacturing global supply chains. The methodology provides a holistic approach to consider all supply chains associated with manufacture. It also encourages a facilitated decisionmaking process for sharing ideas, information, and opinions from employees. The primary and secondary evaluation have been very valuable in building confidence that the SPGC methodology is a generic and practical methodology that provides an integrated and holistic approach for assisting manufacturers to deal with strategic positioning within global supply chains.

In future studies it is necessary to further evaluate the methodology with more case studies. This would provide a better understanding of the methodology and may lead to further refinement. Future study could also focus on sector-specific industry, for example the oil, chemical, and automotive industries, etc. This could explore how 
manufacturers position themselves strategically within specific sectors in order to obtain an understanding of sectorspecific characteristics, success factors, pitfalls, and the limitations of strategic positioning of each sector.

\section{REFERENCES}

1 EEF (Engineering Employers' Federation). Where now for manufacturing? , 2004 (EEF, London, UK).

2 Bhatnagar, R. and Viswanathan, S. Re-engineering global supply chains: alliances between manufacturing firms and global logistics services providers. Int. J. Physical Distribution \& Logistics Mgmt , 2000, 30 (1), 13-34.

3 Prasad, S. and Sounderpandian, F. Factors influencing global supply chain efficiency: implications for information systems. Int. J. Supply Chain Mgmt , 2003, 8 (3/4), 241-250.

4 The Manufacturing Foundation, KPMG and the DTI Manufacturing Advisory Service. Offshore? Be sure! , 2006 (The Manufacturing Foundation, Wolverhampton).

5 EEF - Engineering Employers' Federation. Global challenges - opportunities and threats for UK manufacturers , 2007 (EEF, London, UK).

6 EEF - Engineering Employers' Federation. Manufacturing performance 2006/7 , 2007 (EEF, London, UK).

7 BERR (Department for Business Enterprise \& Regulatory Reform). The government's manufacturing strategy , 2002 (BERR, London, UK).

8 BERR (Department for Business Enterprise \& Regulatory Reform). Review of the Government's manufacturing strategy , 2004 (BERR, London, UK).

9 Porter, M. E. What is strategy? Harv. Bus. Rev. 1996, 74 (6), 61-78.

10 Kalafatis, S. P., Tsogas, M. H., and Blankson, C. Positioning strategies in business markets. J. Bus. Ind. Marketing , 2000,15 (6), $416-437$.

11 Vrontis, D. and Sharp, I. The strategic positioning of Coca-Cola in their global marketing operation. The Marketing Rev., 2003,3 , 89-309.

12 Gallaugher, J. Strategic positioning and resource-based thinking: cutting through the haze of punditry to understand factors behind sustainable, successful internet businesses. Int. J. E-Bus. Res. , 2007, 3 (3), 14-25.

13 Hill, T. J. Manufacturing strategy: the strategic management of the manufacturing function , 1993 (Macmillan Press Ltd, Basingstoke, Hants., UK).

14 Vallespir, B. and Kleinhans, S. The positioning of the company in enterprise collaborations. Prod. Planning Control , 2001,12 (5), $478-487$.

15 Johansen, J. and Riis, J. O. The interactive firm - towards a new paradigm. A framework for the strategic positioning of the industrial company of the future. Int. J. Op. Prod. Mgmt , 2005, 25 (2), 202-216.

16 Baines, T., Kay, G., Adesola, S., and Higson, M. Strategic positioning: an integrated decision process for manufacturers. Int. J. Op. Prod. Mgmt , 2005, 25 (2), 180- 201.

17 Watson, E., MacBryde, J., Burns, N., Szwejczewski, M., Randle, B., Higon, D. A., and Battisti, G. Repositioning in the value chain: How can companies do it and is it worth it? In Proceedings of EurOMA 13th International Annual Conference: Moving up the value chain , Glasgow, 2006.

18 Strategic Direction. How Zara fashions its supply chain. Strategic Direction , 2005, 21 (10), 28-32.

19 Sull, D. and Turconi, S. Fast fashion lessons. Bus. Strategy Rev., 2008, 19 (2), 4-11.

20 Richard, P. Rulers of the high street. Brand Strategy , 2008, (221), 56-57.

21 Lim, R. Y. G., Baines, T., Tjahjono, B., and Chandraprakaikul, W. Integrated strategic supply chain positioning for SMEs: an empirical study. Int. J. Logistics Mgmt , 2006, 17 (2), 260-276.

22 Lim, R. Y. G. Development of a strategic supply chain positioning methodology for SMEs in Singapore . EngD Thesis, Cranfield University, 2007.

23 Chai, K-H., Yap, C-M., and Pellerin, M. Manufacturing capability networks: a case study on production allocation decision in the pharmaceutical industry. Proc. IMechE, Part B: J. Engineering Manufacture., 2009, 223 (B7), 885-903. DOI: 10.1243/09544054JEM1353.

24 Handfield, R. and Melynk, S. The scientific theorybuilding process: a primer using the case of TQM. J. Oper. Mgmt, 1998, 16 (4), 321-340. 
25 Eisenhardt, K. M. Building theories from case study research. Academy of Mgmt Rev., 1989, 14 (4), 532-550.

26 Lemke, F. Exploring the link between relationship quality and loyalty . PhD Thesis. Cranfield University, 2003.

27 Hartley, J. Essential guide to qualitative methods in organizational research , 2004 (SAGE Publications Ltd, London).

28 Pongpanich, C. Manufacturing location decisions: choosing the right location for international manufacturing facilities , 2000 (Institute for Manufacturing, University of Cambridge, Cambridge).

29 Probert, D. R. Developing a make or buy: strategy for manufacturing business , 1997 (The Institution of Electrical Engineers, Stevenage, Herts, UK).

30 Maylor, H. and Blackmon, K. Researching business and management, 2005 (Harvey Maylor and Kate Blackmon, New York).

31 Yin, R. K. Case study research - design and methods , 2003 (Sage Publications, California).

32 Treacy, M. and Wiersema, F. The discipline of market leaders: choose your customers, narrow your focus, dominate your market , 1995 (Perseus Publishing, New York) 
Usual supply chain boundaries concerned

\begin{tabular}{|c|c|c|c|c|c|}
\hline Concepts & Supplier & Customer & Infrastructure & Product range & Decision \\
\hline Strategic positioning within global supply chains & • & • & $\bullet$ & $\bullet$ & 0 \\
\hline Manufacturing location & $\square$ & $\square$ & 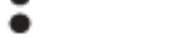 & $\square$ & \\
\hline Make or buy & & $\square$ & 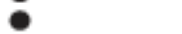 & $\square$ & 0 \\
\hline Vertical integration & 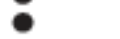 & 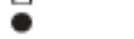 & $\square$ & 口 & 0 \\
\hline Horizontal integration & $\square$ & $\square$ & 口 & 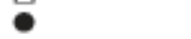 & 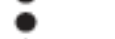 \\
\hline Sourcing & 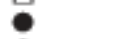 & $\square$ & $\square$ & $\square$ & 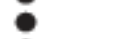 \\
\hline Supplier selection & 6 & 口 & $\square$ & ㅁ & 0 \\
\hline Strategic alliances & 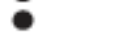 & $\mathrm{O}$ & $\square$ & 口 & 0 \\
\hline Core competency & 0 & $\mathrm{O}$ & $\mathrm{O}$ & $\mathrm{O}$ & 0 \\
\hline Outsourcing & 0 & $\square$ & 0 & $\square$ & - \\
\hline Offshoring & & 口 & & 0 & \\
\hline
\end{tabular}

- Intended to be used for $O$ Can be used for $\square$ Not intended for

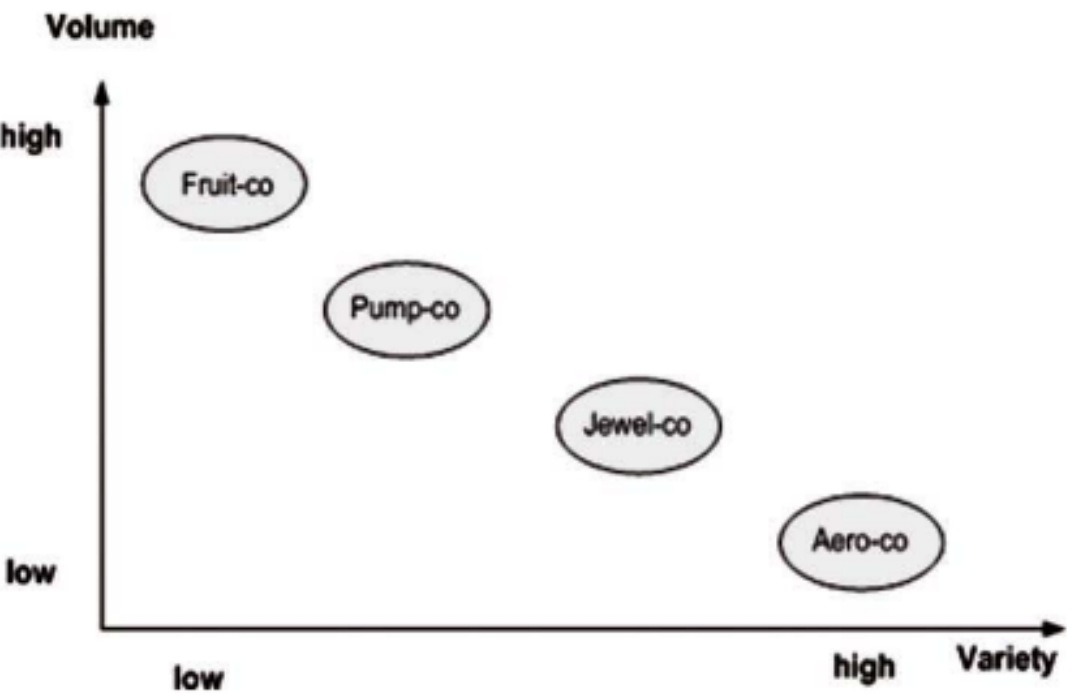

APPENDIX 3 OFFSHORING AND OFFSHORE OUTSOURCING CHART OF CASE STUDIES' EXPERIENCES IN PHASE 1

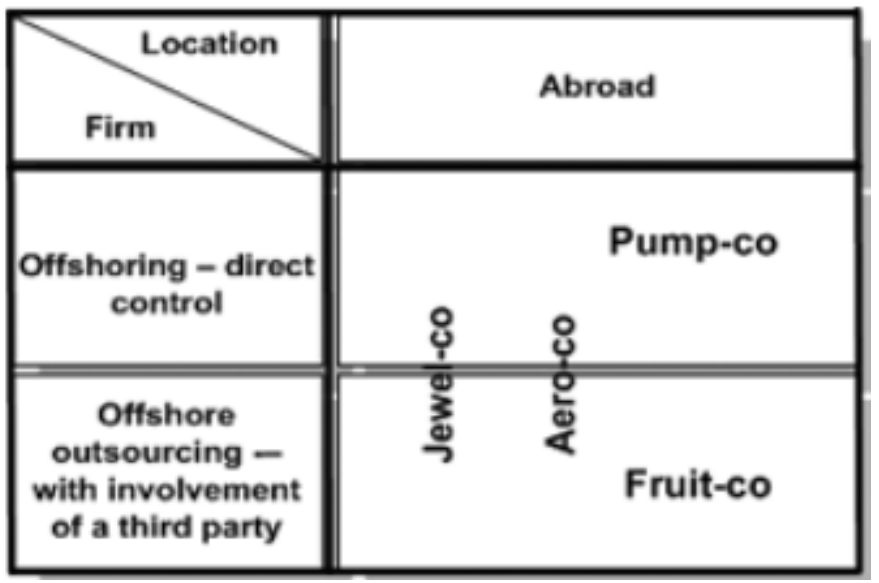


Provides a holistic approach concerning four supply chain boundaries to decide a strategic position of an organization. Provides financial and non-financial factors for deciding actions.

Provides an analysis of business issues in order to enable establishing a clear aim and scope of the decision.

Supports a decision for strategic positioning within global supply chains.

Provides configuration analysis for strategic positioning within global supply chains.

\section{APPENDIX 5 COMPANY SELECTION CRITERIA IN PHASE 4}

1. The scope of the project has to be big enough to test the validity of the pilot methodology but small enough to be carried out completely by the researcher as the user and facilitator.

2. The company should be considering a global supply chain positioning improvement initiative.

3. The company should have no methodology in place and is exploring a new structured approach.

\section{APPENDIX 6 CHARACTERISTICS OF PARTICIPATING COMPANIES IN PHASE 4}

\begin{tabular}{lll}
\hline & Elec-co & Amp-co \\
\hline Size & 300 employees & 250 employees \\
Ownership & UK owner & UK owner \\
Location & UK & UK \\
Industry segment & Manufacturer of electronic drives for the & Manufacturer of music \\
& control of electric motors & amplifiers
\end{tabular}

\section{APPENDIX 7 CHARACTERISTICS OF PARTICIPATING COMPANIES IN PHASE 5}

\begin{tabular}{llll}
\hline & Steel-co & Garment-co & Tool-co \\
\hline Size & 50 employees & 660 employees & Tyre-co employees \\
Ownership & German group & Thai owner & Japanese group employees \\
Location & UK & Thailand & Singapore \\
Industry segment & Manufacturer of special tool steel & $\begin{array}{l}\text { Manufacturer of casual apparel and } \\
\text { sport wear products }\end{array}$ & Manufacturer of machine tools $\quad$ Manufacturer of tyres, wheels \\
Facilitator & Operations manager & Quality manager & Consultant
\end{tabular}




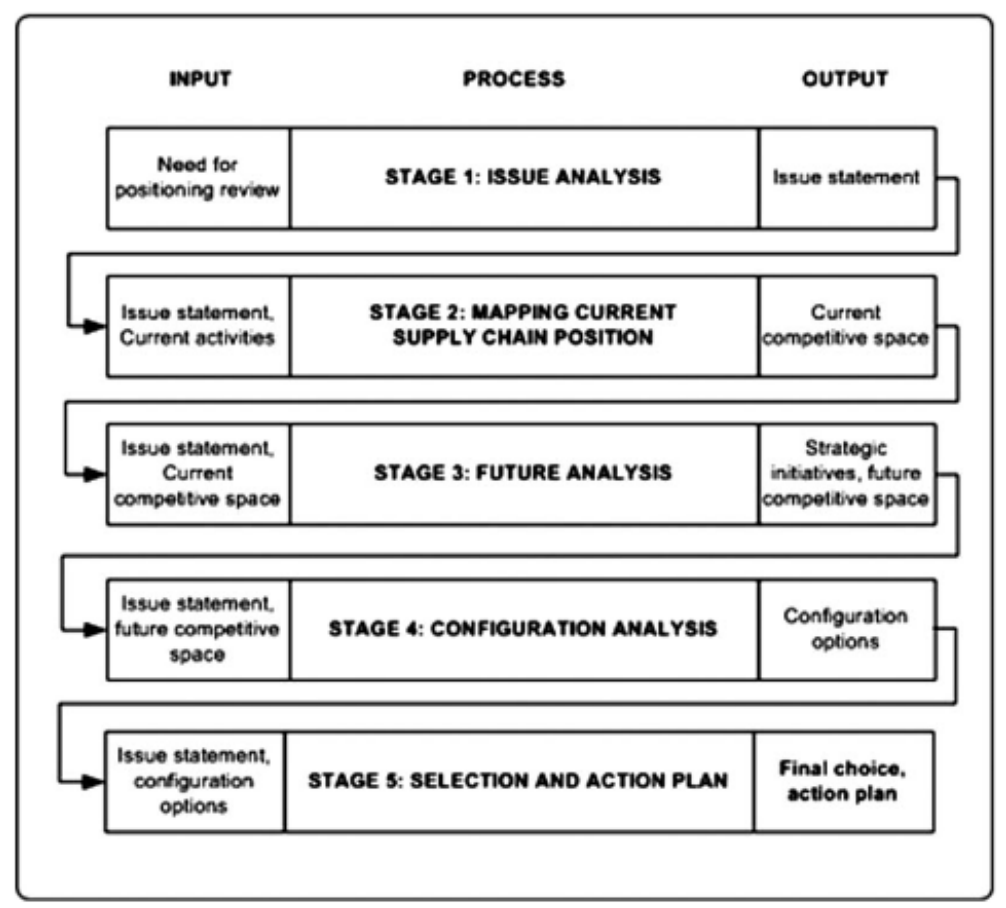

\section{APPENDIX 13 STAGE 3 OF THE SPGC METHODOLOGY}

Stage 3: Future analysis

Identify those activities that have significance to the issue statement, and from this, analyse and propose immediate associated initiatives

Section 3.1 Identify significant activities

Section 3.2 Assess changes for significant activities

Section 3.3 Propose actions for significant activities
Output: Significant activity map

Output: Assessment of significant activities

Output: Strategic initiatives and future competitive space 
1. Financial factors

Net present value, return on investment, profit margin, payback period, growth potential, cost of implementation

2. Performance factors

Performance objectives from competitive strategies: service customization, product customization (design flexibility), after-sales support, product availability (delivery reliability), product price (total cost), quality conformance, product attributes, time to market, new product introduction rate

Supply chain: supply chain flexibility (response time, production flexibility), supply chainreliability, supply chain responsiveness

4. Business risks

Intellectual property protection, poor service quality, lack of cultural fit, lack of control, lack of client acceptance, operational inefficiency, infrastructure instability, political instability, disaster recovery, longevity of new position, irreversibility (partly, completely), confidentiality leaks, loss of strategic flexibility, employee morale, employee turnover threatened the transfer of knowledge to the new location, currency risk, supply disruption, etc.

3. Geographical factors

\begin{tabular}{|c|c|}
\hline Categories & Factors \\
\hline Labour characteristics & $\begin{array}{l}\text { Quality of labour force, availability of labour force, unemployment rate, labour unions, attitudes towards work and labour turnover, } \\
\text { motivation of workers and work- } \\
\text { force management }\end{array}$ \\
\hline Infrastructure & $\begin{array}{l}\text { Existence of modes of transportation, quality and reliability of modes of transportation, quality and reliability of utilities, and } \\
\text { telecommunication systems }\end{array}$ \\
\hline Quality of life & $\begin{array}{l}\text { Cost of living, society's attitudes towards an industry, extent of English language usage, schools and universities, crime rates, record of } \\
\text { natural disasters, availability and quality of hospitals, hotels and banks, community environment }\end{array}$ \\
\hline Competition & $\begin{array}{l}\text { Potential response from major competitors, number of competitors in the area, potential new competitors from the area, sales in the area } \\
\text { for the last five years, compared with competitors }\end{array}$ \\
\hline Suppliers & $\begin{array}{l}\text { Availability of suppliers and subcontractors, quality of suppliers and subcontractors, alternative suppliers, competition for materials from } \\
\text { other companies }\end{array}$ \\
\hline Integration with customers & Proximity to market, size of market, stability of market conditions, facilitation of post-sale service, facilitation of co-design \\
\hline $\begin{array}{l}\text { Legal and regulatory } \\
\text { framework }\end{array}$ & $\begin{array}{l}\text { Compensation law, insurance law, environmental regulations, industrial relations laws, legal system, bureaucratic red tape, requirements } \\
\text { for setting up local operations, regulations concerning joint ventures and mergers and regulations on transfer of earnings out of country } \\
\text { rate }\end{array}$ \\
\hline Economic factor & $\begin{array}{l}\text { Tax structure and tax incentives, financial incentives, custom duties, tariffs, inflation, strength of currency against US dollar, business } \\
\text { climate, country's debt, interest rates/ exchange controls and GDP/GNP growth, income per capita }\end{array}$ \\
\hline $\begin{array}{l}\text { Government and political } \\
\text { factors }\end{array}$ & Record of government stability, government structure, consistency of government policy, and attitude of government to inward investment \\
\hline
\end{tabular}

\section{APPENDIX 15 STAGE 4 OF THE SPGC METHODOLOGY}

Stage 4: Configuration analysis

Conduct analysis to generate detailed analysis of promising configuration options

\begin{tabular}{ll}
\hline Section 4.1 Identify potential configuration options & Output: Potential configuration options \\
Section 4.2 Identify short-list configuration options & Output: Short-list configuration options \\
Section 4.3 Detailed analysis of each option & Output: Detailed analysis of each option \\
\hline
\end{tabular}

\section{APPENDIX 16 STAGE 5 OF THE SPGC METHODOLOGY}

Stage 5: Selection and action plan

Select the most appropriate configuration option, check alignment to earlier stages, and develop a plan for implementation activities

Section 5.1 Select the most appropriate option

Section 5.2 Establish draft plan

Section 5.3 Establish action plan
Output: Selected configuration option

Output: Draft plan

Output: Action plan 


\begin{tabular}{|c|c|}
\hline Business area UK & Tool Steel \\
\hline Overriding issues & $\begin{array}{l}\text { Increase sales - development of market opportunities. } \\
\text { Condition of machine tools. } \\
\text { Plant layout/appearance - corporate standards. }\end{array}$ \\
\hline Business strategies & $\begin{array}{l}\text { Differentiation focused - complete supply/added value. } \\
\text { Customer intimacy. }\end{array}$ \\
\hline Internal and external analysis & $\begin{array}{l}\text { S - Brand reputation/support from group steel mills. } \\
\text { W - Plant maintenance/inventory costs/skilled machinists. } \\
\mathrm{O} \text { - Penetration in existing UK and European markets. } \\
\mathrm{T} \text { - Competition from cheaper imports/exchange rate. }\end{array}$ \\
\hline Critical performance gaps & $\begin{array}{l}\text { The desired competitive strategy focuses on extension of customer } \\
\text { intimacy, and aims to further exceed expectations in } \\
\text { service/product customization, after-sales support and product } \\
\text { availability. }\end{array}$ \\
\hline Issue statement & $\begin{array}{l}\text { Evaluate manufacturing and distribution in the UK: either (i) } \\
\text { investing in existing plant, or } \\
\text { (ii) relocate to alternative premises/outsource (within group) } \\
\text { machining operations. }\end{array}$ \\
\hline
\end{tabular}

\section{APPENDIX 18 SUPPLY CHAIN POSITION OF STEEL-CO}

\begin{tabular}{lllll}
\hline Location & UK & Europe & Asia & North America \\
\hline Raw material suppliers (\%) & 54 & 23 & 5 & 0 \\
Internal functions & $\begin{array}{l}\text { Warehouse and distribution, } \\
\text { accounting and admin, } \\
\text { manufacturing, sales }\end{array}$ & Machining & & \\
Outsourcing suppliers & Machining & 12 & 3 \\
Customers (\%) & 85 & 3 & 3 \\
\hline
\end{tabular}

\section{APPENDIX 19 CORE ACTIVITY POSITION OF STEEL-CO}

\begin{tabular}{|c|c|c|c|c|}
\hline $\begin{array}{l}\text { Raw material } \\
\text { supplors }\end{array}$ & UK supplier & $\begin{array}{c}\text { The group in } \\
\text { USA }\end{array}$ & $\begin{array}{l}\text { Supplier in } \\
\text { Europe }\end{array}$ & $\begin{array}{c}\text { Supplierin } \\
\text { Asia }\end{array}$ \\
\hline Outsourcing & & & Machining & \\
\hline $\begin{array}{l}\text { Warehouse } \\
\text { and } \\
\text { distribution }\end{array}$ & Purchasing & Warchouaing & & \\
\hline $\begin{array}{l}\text { Aceounting } \\
\text { and admin }\end{array}$ & Accounting & HR & Admin & $\pi$ \\
\hline Manufactuiting & Sawing & Heat Ireatment & Testing & Machining \\
\hline Sales & $\begin{array}{l}\text { Salos and } \\
\text { makketing }\end{array}$ & Cuotation & $\begin{array}{l}\text { Order } \\
\text { processing }\end{array}$ & \\
\hline Customers & Customer & & & \\
\hline
\end{tabular}




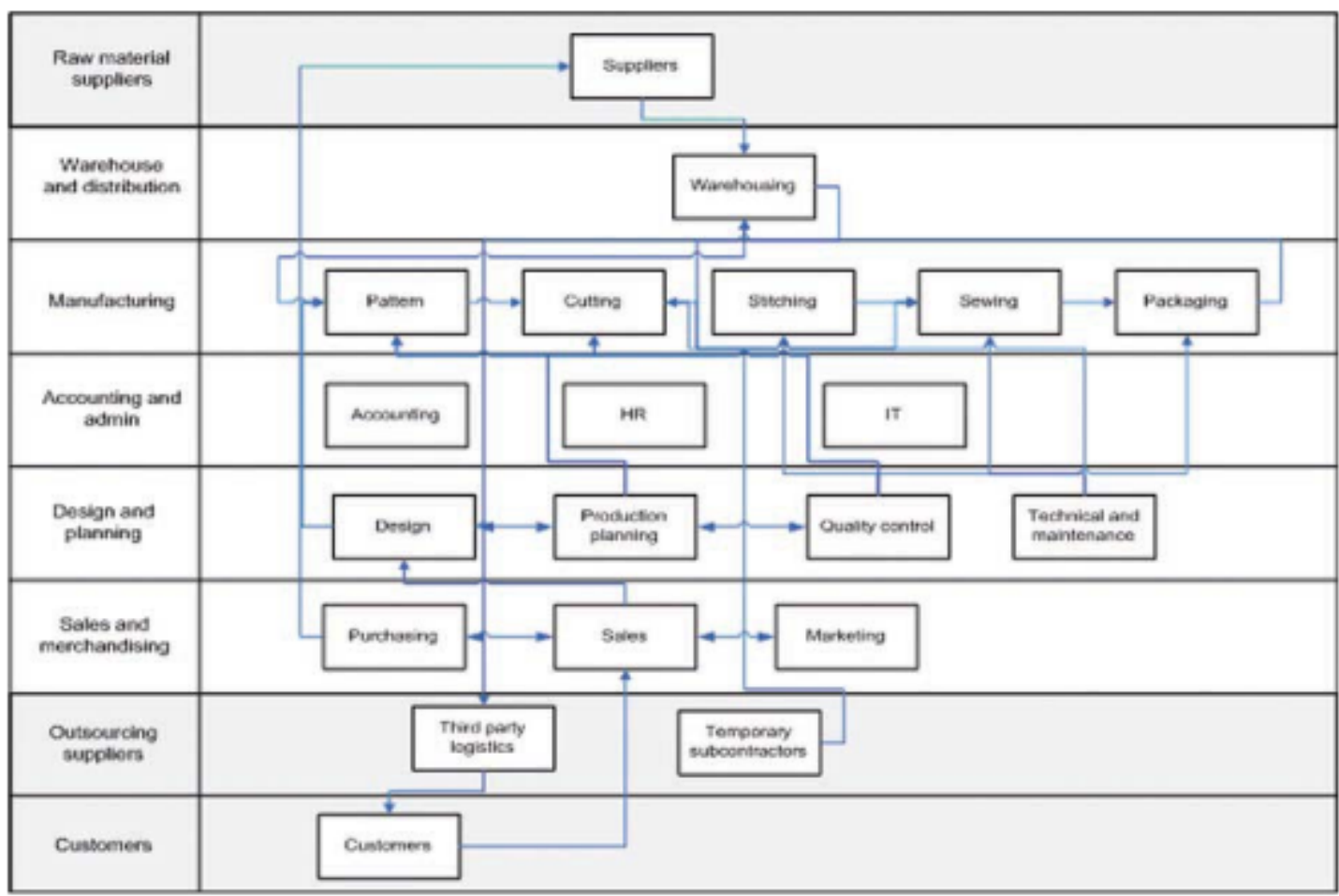

\section{APPENDIX 21 SIGNIFICANT ACTIVITIES AND PROPOSED ACTIONS}

\begin{tabular}{|c|c|c|}
\hline Significant activities & Proposed actions & Initiatives \\
\hline Warehousing & Keep and strengthen & Apply real time stock and get rid of old stock \\
\hline Production planning & Keep and strengthen & Coordinate with sales team for sales and operation planning \\
\hline Purchasing & Keep and strengthen & $\begin{array}{l}\text { Study the history of purchasing and analyse factors of waste in purchasing, improve supplier relationship, } \\
\text { share information between the company and suppliers, review the supply chain evaluation system }\end{array}$ \\
\hline Physical flows in manufacturing & Strengthen & Reduce waste in the process, change forms, improve visibility of physical movements in the production \\
\hline Sales & Strengthen & $\begin{array}{l}\text { Review customer segmentation, analyse customer satisfaction, customer trend and work on collaboration } \\
\text { with customers }\end{array}$ \\
\hline Marketing & Strengthen & Enhance company image, apply web-based system to communicate with customers \\
\hline Design & Grow & Change the procedure method and encourage new design \\
\hline
\end{tabular}

